\title{
The Association of obesity with vascular complications after liver transplantation
}

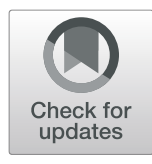

\author{
Yi Shi $^{\dagger}$, Bingsong Huang ${ }^{\dagger}$, Ronghai Deng ${ }^{*}$ and $\mathrm{Yi} \mathrm{Ma}^{*}$
}

\begin{abstract}
Background: Because of the growing number of obese patients undergoing liver transplantation (LT), it is important to investigate the impact of obesity on post-transplant outcomes. Vascular complications are rare, but serious causes of morbidity and mortality after LT. It is not known if pre-transplant obesity is associated with an increased incidence of post-LT vascular complications.

Methods: Medline, Embase, and Cochrane Library databases were searched in September 2017. The primary outcome was the impact of obesity on the vascular complication rate in adult LT recipients. Survival and biliary complications rates were also analyzed. Risk ratios (RRs) and 95\% confidence intervals (Cls) were calculated to compare pooled data between groups with a body mass index $(\mathrm{BMI}) \geq 30 \mathrm{~kg} / \mathrm{m}^{2}$ and $<30 \mathrm{~kg} / \mathrm{m}^{2}$.

Results: Six retrospective cohort studies with a total of 987 patients with a BMI $\geq 30 \mathrm{~kg} / \mathrm{m}^{2}$ (high BMI group) and 2911 patients with a BMl $<30 \mathrm{~kg} / \mathrm{m}^{2}$ (control group) were included in the analysis. All studies had NewcastleOttawa Scale scores $\geq 4$. The vascular complication rates were similar between the high BMI group and control group ( $\mathrm{RR}=1.13,95 \% \mathrm{Cl}: 0.87-1.47, P=0.27$ ), as were the patient survival, graft survival, and biliary complication rates. In subgroup analysis, there was no difference in the vascular complication rates between $\mathrm{BMl} \geq 35 \mathrm{vs}$. BMl< $25 \mathrm{~kg} / \mathrm{m}^{2}$; BMl $30-35$ vs. BMl $18-25 \mathrm{~kg} / \mathrm{m}^{2} ; \mathrm{BMl} \geq 30$ vs. BMl $18-25 \mathrm{~kg} / \mathrm{m}^{2} ;$ and $\mathrm{BMl} \geq 35 \mathrm{vs}$. BMl $<35 \mathrm{~kg} / \mathrm{m}^{2}$. No difference was found in subgroup analysis when BMI was adjusted for ascites. However, recipients whose primary disease was alcoholic liver disease, those with a $\mathrm{BMI} \geq 30 \mathrm{~kg} / \mathrm{m}^{2}$ had higher incidence of vascular complications than those with a $\mathrm{BMI}<30 \mathrm{~kg} / \mathrm{m}^{2}(\mathrm{RR}=1.55,95 \% \mathrm{Cl}: 1.07-2.25, P=0.02)$.
\end{abstract}

Conclusions: BMI does not affect incidence of vascular complications after LT. High pre-transplant BMI is not a risk factor for patient survival and biliary complications after LT.

Keywords: Liver transplantation, Vascular complications, Obese, Body mass index, Meta-analysis

\section{Introduction}

The World Health Organization (WHO) reported that $13.2 \%$ of global adults were obese in 2016 [1]. Obesity has become a global epidemic that contributes to a number of comorbidities and metabolic disorders [2,3]. Furthermore, the number of obese patients undergoing liver transplantation (LT) is rising rapidly in the United States [4-6], and in the rest of the world. The proportion of obese patients in LT recipients was 33\% between 2002 and 2011 [7], as compared to 20\% between 1988 and 1996 [8]. Moreover, it was recently reported that

\footnotetext{
*Correspondence: mddrh81@163.com; anhuimayi2002@163.com

${ }^{\dagger}$ Yi Shi and Bingsong Huang contributed equally to this work.

${ }^{\dagger}$ Yi Shi and Bingsong are co-first-authors.

Department of Organ Transplantation, First Affiliated Hospital of Sun Yat-sen University, No. 58 Zhongshan 2nd Road, Guangzhou 510080, China
}

severely and morbidly obese patients (body mass index $\left.[\mathrm{BMI}]>35 \mathrm{~kg} / \mathrm{m}^{2}\right)$ patients account for $7-12 \%$ of LT recipients $[8,9]$.

As the number of patients on the transplant waiting list is increasing, and with the lack of sufficient donors to meet this demand, it is important to predict the prognosis of every candidate to help decide the allocation of donor livers. Vascular complications after LT are associated with a high incidence of graft loss and mortality because of the impact on blood flow [10]. Bleeding, stenosis, thrombosis, and an aneurysm can occur at any vascular anastomoses, with a reported rate of $8-15 \%$ [11]. Causes of vascular complications include technical problems in anastomosis and allograft anatomy [12]. La Mattina et al. [13] reported that obesity may be a risk factor

(c) The Author(s). 2019 Open Access This article is distributed under the terms of the Creative Commons Attribution 4.0 International License (http://creativecommons.org/licenses/by/4.0/), which permits unrestricted use, distribution, and 
for vascular complications after LT. The authors reviewed $813 \mathrm{LT}$ recipients, and divided them into 5 groups according to BMI. There was a significantly higher rate of deep venous thrombosis in patients with a BMI $>40 \mathrm{~kg} / \mathrm{m}^{2}$ compared to those with a normal BMI. Other studies also reported that obese LT recipients had a trend toward a higher risk of vascular complications after transplantation, though differences between groups were not statistically significant $[14,15]$. On the other hand, a retrospective cohort study including $1325 \mathrm{LT}$ recipients showed that obese patients had a slightly decreased rate of vascular complications, but again the difference between groups was not significant [16]. Spengler et al. [17] reviewed studies that reported morbidity after LT in obese versus non-obese patients, and found postoperative infections and respiratory failure occurred more frequently in obese recipients. A meta-analysis by Saab et al. [18] including 13 studies found that obesity negatively impacted survival in LT recipients, but vascular complications were not studied. As such, it is not known if obesity affects the rate of vascular complications after LT.

The objective of this study was to conduct a meta-analysis to determine the impact of BMI on vascular complications in LT recipients.

\section{Materials and methods}

\section{Data sources and literature searches}

PubMed/Medline, Embase, and Cochrane Library databases were searched in September 2017 using the terms "complication or complications" AND "body mass index or overweight or obesity or obese" AND "liver transplant or liver transplantation". Eligible publications were limited to those written in English, and to those reporting results from human subjects. Review and meta-analysis articles were excluded after limit filtering. A manual search of the references of relevant publications was also performed.

\section{Study inclusion and exclusion criteria}

Studies reporting outcomes of LT in different preoperative BMI groups were included. Exclusion criteria were: 1) Overlapping cohort studies from the same institution (to avoid duplication); 2) Studies in which post-transplantation vascular complications were not reported in patients with a $\mathrm{BMI} \geq 30 \mathrm{~kg} / \mathrm{m}^{2}$ and those with a $\mathrm{BMI}<30 \mathrm{~kg} / \mathrm{m}^{2}$; 3) Studies of pediatric patients.

\section{Quality assessment and data extraction}

The methodological quality of observational studies was determined using the Newcastle-Ottawa Scale. 'Selection,' 'comparability', and 'outcome' are the 3 categories included in the Newcastle-Ottawa Scale for cohort studies. Publications were assessed and data were extracted by 2 independent investigators, with disagreements resolved through discussion and consensus.
The primary outcome of the meta-analysis was the incidence of vascular complications following LT, which were comprised of stenosis, thrombosis, and pseudoaneurysm. Secondary outcomes were biliary complications, and patient and graft survival rates. Given that BMI is a universal measure to determine obesity, a $\mathrm{BMI} \geq 30 \mathrm{~kg} / \mathrm{m}^{2}$ was chosen as the criterion of obesity. Results of patients with a $\mathrm{BMI} \geq 30 \mathrm{~kg} / \mathrm{m}^{2}$ were compared with those of patients with a BMI $<30 \mathrm{~kg} / \mathrm{m}^{2}$.

\section{Data synthesis and analysis}

Risk ratios (RRs) were used to evaluate the event rates, and the results were reported with $95 \%$ confidence intervals $(\mathrm{CIs}) . P$ values $<0.05$ were considered to indicate a significant difference between the 2 groups. Heterogeneity of the included studies was evaluated by the $x^{2}$ and $\mathrm{I}^{2}$ statistical tests. Heterogeneity was considered significant when $x^{2}$ value of $\mathrm{P}$ was $<0.05$, or $\mathrm{I}^{2}$ was $>50 \%$ : in this case a random-effects model of analysis was used. When significant heterogeneity was not identified, a fixed-effects model of analysis was used. Publication bias was assessed by a funnel plot. All statistical analysis was performed using Review Manager software (RevMan Version 5.3).

\section{Results}

Search results and included studies

A total of 984 articles were identified in the database searches (Fig. 1). After excluding animal studies and non-English language reports, 828 studies remained. Of these, 154 review articles and 647 studies not reporting pre-transplant BMI were excluded. The remaining 27 publications underwent extensive review. Seventeen studies lacking data of vascular complications and 1 study [19] of pediatric patients were excluded. There were 2 studies with overlapping cohorts from the same institution [14, 20], and only the latest report [14] was included. Two studies did not use $30 \mathrm{~kg} / \mathrm{m}^{2}$ as the BMI threshold. We requested the primary data from the corresponding authors, but did not receive replies so these studies were excluded from the primary analysis. Finally, 6 studies meeting all of the criteria were included in the meta-analysis. However, the 2 studies in which the BMI threshold was not $30 \mathrm{~kg} / \mathrm{m}^{2}$ were included in the subgroup analysis.

The characteristics of the 8 studies are summarized in Table 1. No evidence of publication bias among the included studies was found by funnel plot examination. In the 6 included studies, there were $2911 \mathrm{LT}$ recipients with a preoperative $\mathrm{BMI}<30 \mathrm{~kg} / \mathrm{m}^{2}$ and 987 with a preoperative BMI $\geq 30 \mathrm{~kg} / \mathrm{m}^{2}$. Three of the studies were from European countries, 2 were from the United States, and 1 was from Canada. When assessed with the Newcastle-Ottawa Scale, 


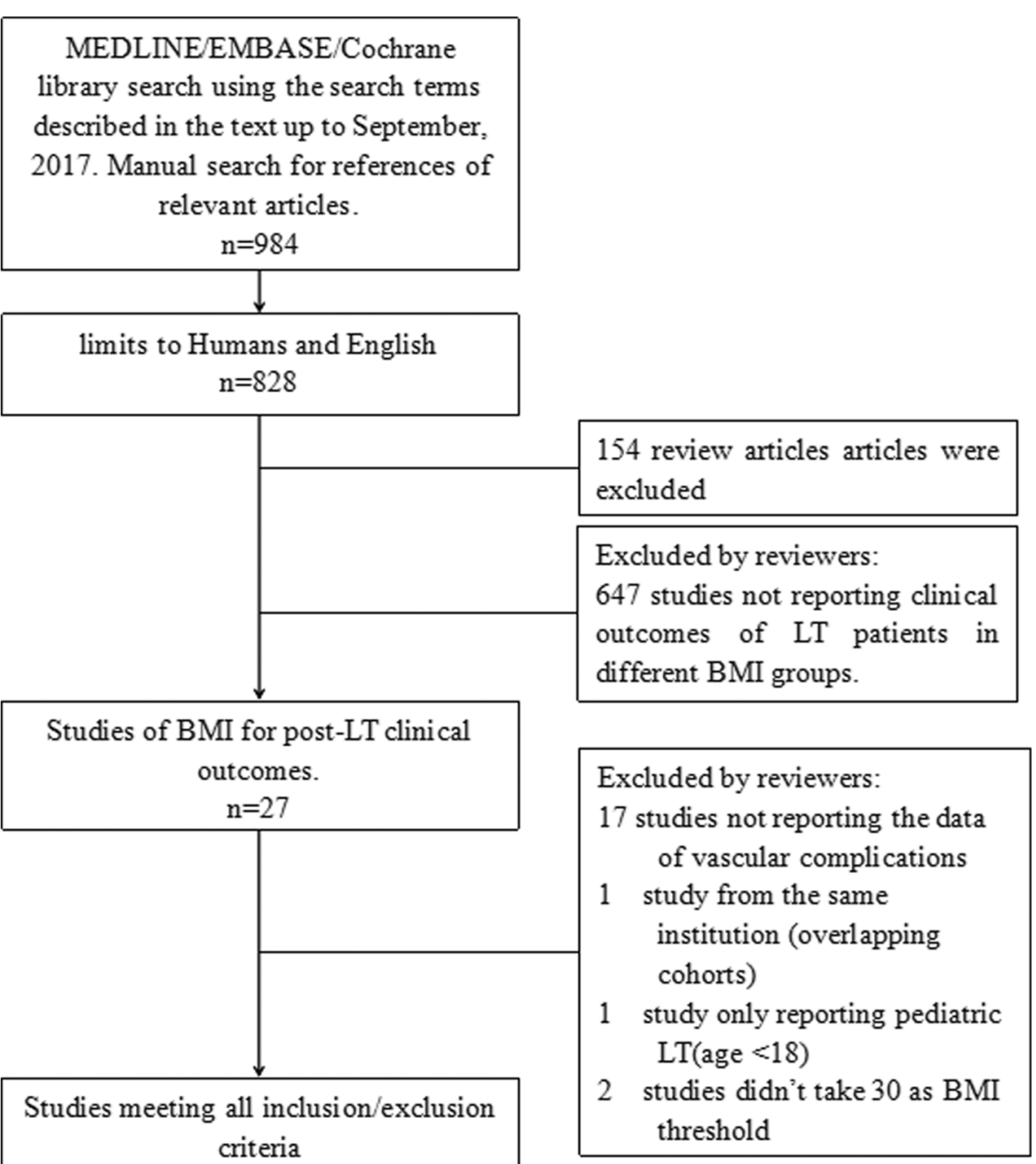

Fig. 1 Search algorithm and study selection

Table 1 Characteristics of the included studies

\begin{tabular}{|c|c|c|c|c|c|c|c|c|c|}
\hline \multirow[t]{2}{*}{ Reference } & \multirow[t]{2}{*}{ Region } & \multicolumn{2}{|l|}{ Sample Size } & \multirow[t]{2}{*}{ Periods } & \multicolumn{2}{|l|}{ Recipient Age } & \multirow{2}{*}{$\begin{array}{l}\text { MELD } \\
\text { Score }\end{array}$} & \multirow{2}{*}{$\begin{array}{l}\text { Male } \\
(\%)\end{array}$} & \multirow{2}{*}{$\begin{array}{l}\text { Most common } \\
\text { etiology }\end{array}$} \\
\hline & & $\mathrm{BMI} \geq 30$ & $\mathrm{BMI}<30$ & & $\mathrm{BMI} \geq 30$ & $\mathrm{BMl}<30$ & & & \\
\hline Nair $(2001)^{a}$ [15] & America & $21^{\Phi}$ & $64^{\mathrm{b}}$ & 1994-1996 & $46.7 \pm 10.5^{\Phi}$ & $46.0 \pm 12.6^{b}$ & / & 82.4 & $\mathrm{HCV}$ \\
\hline Fujikawa (2006) [21] & America & 167 & 533 & 1990-2005 & $51.0 \pm ?$ & $49.5 \pm ?$ & $18.5 \pm ?$ & 61.3 & / \\
\hline Lamattina (2012) [13] & America & 306 & 482 & 1997-2008 & $53.4 \pm 8.8$ & $52.6 \pm 9.9$ & $19.8 \pm 8.8$ & 63.1 & Alcohol \\
\hline Hakeem (2013) [16] & The UK & 218 & 1107 & 1994-2009 & $50.9 \pm 8.5$ & $47.4 \pm 13.0$ & $19.7 \pm 10.7$ & 56.9 & cholestasis \\
\hline Tanaka (2013) [22] & Canada & 149 & 358 & 2000-2006 & $52.9 \pm 8.6$ & $51.4 \pm 10.5$ & $16.2 \pm 8.0$ & 69.0 & $\mathrm{HCV}$ \\
\hline Gunay (2013) [23] & Europe & 74 & 296 & 2004-2012 & $52.4 \pm 8.4$ & $50.4 \pm 11.3$ & $16.7 \pm 6.6$ & 76.8 & HBV \\
\hline Triguero $(2015)^{\mathrm{a}}$ [24] & Europe & $11(\mathrm{BMI}>35)$ & 36(BMI 20-25) & 2007-2013 & $53 \pm ?(45-64)$ & $54.5 \pm ?$ & $15 \pm ?$ & 78.7 & Alcohol \\
\hline Molina (2016) [14] & Europe & 73 & 135 & 2008-2014 & $54.8 \pm 7.7$ & $52.8 \pm 10.3$ & $18.2 \pm 5.0$ & 84.1 & Alcohol \\
\hline
\end{tabular}

${ }^{a}$ These studies were not included because of inconsistent grouping with others. $\Phi$ : $\mathrm{BMI}>31.1$ for men and 32.3 for women

${ }^{\mathrm{b}} \mathrm{BMI}<27.8$ for men and < 27.3 for women; MELD: model for end-stage liver disease; HBV: hepatic B virus; HCV: hepatic C virus 
all studies obtained a score $\geq 4$ stars, with a highest score of 6 (Table 2).

\section{Vascular complications}

Six studies reported the incidence of vascular complications in patients with a $\mathrm{BMI} \geq 30 \mathrm{~kg} / \mathrm{m}^{2}$ and $\mathrm{BMI}<30 \mathrm{~kg} / \mathrm{m}^{2}$ $[13,14,16,21-23]$. Additionally, we also included the 2 studies in which the BMI threshold was not $30 \mathrm{~kg} / \mathrm{m}^{2}$ in subgroup analysis. The study by Triguero et al. included 2 groups: $\mathrm{BMI} \geq 35 \mathrm{~kg} / \mathrm{m}^{2}$ and BMI $18-25 \mathrm{~kg} / \mathrm{m}^{2}$ [24]. The study by Nair et al. divided women into those with a BMI $<27.3 \mathrm{~kg} / \mathrm{m}^{2}$, BMI $27.3-32.3 \mathrm{~kg} / \mathrm{m}^{2}$, and BMI $>32.3 \mathrm{~kg} / \mathrm{m}^{2}$, and men into those with a BMI $<27.8 \mathrm{~kg} / \mathrm{m}^{2}, \mathrm{BMI}$ $27.8-31.1 \mathrm{~kg} / \mathrm{m}^{2}$, and $\mathrm{BMI}>31.1 \mathrm{~kg} / \mathrm{m}^{2}$ [15]. We excluded the intermediate classes, and used the remaining 2 groups as the control and high BMI group.

None of the studies reported a significant difference in the vascular complication rate between BMI groups. The overall rate of vascular complications among the 6 studies was 12.50\% (range: $2.29-40 \%$ ) for $\mathrm{BMI} \geq 30 \mathrm{~kg} / \mathrm{m}^{2}(n=987)$, and 6.15\% (range: $3.04-8.71 \%$ ) for $\mathrm{BMI}<30 \mathrm{~kg} / \mathrm{m}^{2} \quad(n=2911)$. There was no significant heterogeneity among the 6 studies $\left(X^{2}=6.23, P=0.28 ; I^{2}=20 \%\right)$. Thus, a fixed-effects model of analysis was used. The pooled result of the 6 studies showed that the RR for vascular complications was 1.13 (95\% CI: $0.87-1.47)$ for $\mathrm{BMI} \geq 30 \mathrm{~kg} / \mathrm{m}^{2}$ as compared to a $\mathrm{BMI}<30$ $\mathrm{kg} / \mathrm{m}^{2}(P=0.36)$ (Fig. 2). If the other 2 studies in which the BMI threshold was not $30 \mathrm{~kg} / \mathrm{m}^{2}$ were also included, the difference in the vascular complications rate between the high BMI group and control group was still not significant $(\mathrm{RR}=$ 1.13, 95\% CI: 0.88-1.46, $P=0.34$ ).

Considering that the study by Nair et al. whose patients underwent LT between 1994 and 1996 was relatively old, we excluded it and analyzed the remaining 7 studies. No significant difference in the vascular complication rate was noted $(\mathrm{RR}=1.11,95 \% \mathrm{CI}: 0.86-1.44, P=0.41)$. There were 3 studies that reported the incidence of hepatic arterial thrombosis (HAT) and portal venous thrombosis (PVT) $[13,21,23]$. No significant difference in HAT incidence was found between patients with a BMI $\geq 30 \mathrm{~kg} / \mathrm{m}^{2} \quad(n=547)$ and $\mathrm{BMI}<30 \mathrm{~kg} / \mathrm{m}^{2}(n=1311)(\mathrm{RR}=1.35,95 \% \mathrm{CI}: 0.85-$ 2.13, $P=0.20)$. PVT incidence was also similar between patients with a BMI $\geq 30 \mathrm{~kg} / \mathrm{m}^{2}(\mathrm{n}=547)$ and $\mathrm{BMI}<30 \mathrm{~kg} / \mathrm{m}^{2}$ $(\mathrm{n}=1311)(\mathrm{RR}=1.47,95 \% \mathrm{CI}: 0.87-2.48, P=0.15)$.

\section{BMI threshold}

Data from 4 studies $[13,14,16,22]$ were available to compare the vascular complication rates between LT recipients with a BMI $\geq 35 \mathrm{~kg} / \mathrm{m}^{2}(n=246)$ and a BMI $<25 \mathrm{~kg} / \mathrm{m}^{2}$ ( $n=$ 1149). No difference was found in incidence of vascular complications between these groups ( $R R=1.35$, 95\% CI: $0.81-$ 2.23, $P=0.25$ ) (Additional file 1). Likewise, there was no difference in the incidence of vascular complications between recipients with a BMI of $30-35 \mathrm{~kg} / \mathrm{m}^{2}(n=500)$ and $18-25$ $\mathrm{kg} / \mathrm{m}^{2} \quad(n=1169) \quad(\mathrm{RR}=1.22,95 \%$ CI: $0.80-1.86, P=0.36)$ (Additional file 2) $[13,14,16,22]$. Based on data from 4 studies $[13,16,22,23]$, there was no difference in the incidence of vascular complications incidence between patients with a $\mathrm{BMI} \geq 30 \mathrm{~kg} / \mathrm{m}^{2}(n=747)$ and BMI $18-25 \mathrm{~kg} /$ $\mathrm{m}^{2} \quad(\mathrm{n}=1169) \quad(\mathrm{RR}=1.11,95 \%$ CI: $0.55-2.22, \quad P=0.77)$ (Additional file 3) Subgroup analysis using a BMI threshold of $35 \mathrm{~kg} / \mathrm{m}^{2}$ with data from 4 studies $[13,14,16,22]$ found no difference in the vascular complications incidence between recipients with a $\mathrm{BMI} \geq 35 \mathrm{~kg} / \mathrm{m}^{2}(n=246)$ and a $\mathrm{BMI}<35 \mathrm{~kg} / \mathrm{m}^{2} \quad(n=2568) \quad$ (Additional file 4$) \quad(\mathrm{RR}=$ 1.22, 95\% CI: $0.80-1.85, P=0.36)$.

\section{Ascites}

The pooled analysis of 4 studies $[13,14,16,22]$ which adjusted for the presence of ascites showed no difference in survival between patients with a BMI $\geq 30 \mathrm{~kg} / \mathrm{m}^{2}(n=671)$ and a $\mathrm{BMI}<30 \mathrm{~kg} / \mathrm{m}^{2} \quad(n=2020) \quad(\mathrm{RR}=1.21,95 \% \mathrm{CI}$ : $0.87-1.68, P=0.27$ ) (Additional file 5). Further analysis of pooled studies which corrected BMI for ascites revealed no difference in the rate of vascular complications (BMI 30-35 vs. BMI $18-25 \mathrm{~kg} / \mathrm{m}^{2}: \mathrm{RR}=1.07,95 \% \mathrm{CI}: 0.66-$ $1.74, P=0.77 ; \mathrm{BMI} \geq 35$ vs. $\mathrm{BMI}<35 \mathrm{~kg} / \mathrm{m}^{2}: \quad \mathrm{RR}=1.22$, 95\% CI: $0.80-1.85, \mathrm{P}=0.36)$. No difference was also found in the pooled analysis of studies that did not control for ascites $(\mathrm{RR}=1.01,95 \% \mathrm{CI}: 0.65-1.56, P=0.97)$ [21, 22]. In the analysis, there were 337 patients with a $\mathrm{BMI} \geq 30 \mathrm{~kg} /$ $\mathrm{m}^{2}$ and 955 patients with a BMI $<30 \mathrm{~kg} / \mathrm{m}^{2}$.

\section{Etiology}

Subgroup analysis was performed according to the etiology of liver disease. Alcoholic liver disease was the most common indication for LT in 2 studies [13, 14]. Pooled analysis of the 2 studies showed that the patients with a $\mathrm{BMI} \geq 30 \mathrm{~kg} / \mathrm{m}^{2}(n=379)$ had a significant higher incidence of vascular complications than patients with a $\mathrm{BMI}<30 \mathrm{~kg} / \mathrm{m}^{2}(n=617)(\mathrm{RR}=1.55,95 \% \mathrm{CI}: 1.07-2.25$, $P=0.02)$. In the analysis of pooled data from 2 studies where viral hepatitis was the most common indication for LT $[22,23]$, there was no significant difference in vascular complications between patients with a BMI $\geq 30 \mathrm{~kg} / \mathrm{m}^{2}$ $(n=223)$ and a BMI $<30 \mathrm{~kg} / \mathrm{m}^{2}(n=654)(\mathrm{RR}=0.99,95 \%$ CI: $0.56-1.75, P=0.97)$.

\section{Patient survival}

We evaluate patient survival at 1,3 , and 5 years after transplantation. Three of the 6 included publications reported 1 - and 5-year survival rates [14, 16, 21], and 3 reported 3-year patient survival rates $[14,16,23]$. There was significant heterogeneity among the 3 studies that reported 1-year survival rate $\left(X^{2}=6.60, P=0.04 ; \mathrm{I}^{2}=70 \%\right)$ (Fig. 3). Similarly, significant heterogeneity was observed among the 3 studies reporting 3-year patient survival rates $\left(X^{2}=5.73, P=0.06 ; I^{2}=65 \%\right)$. The heterogeneity was not 


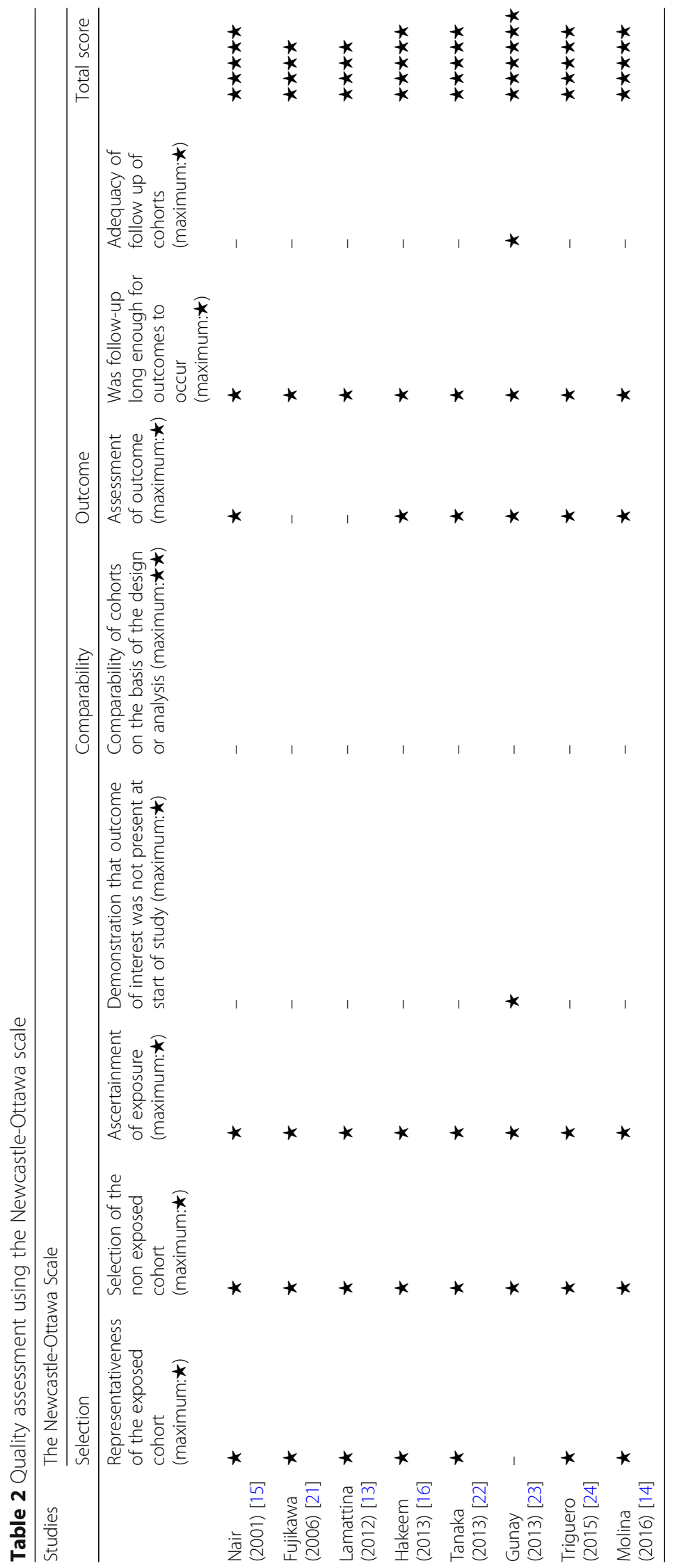




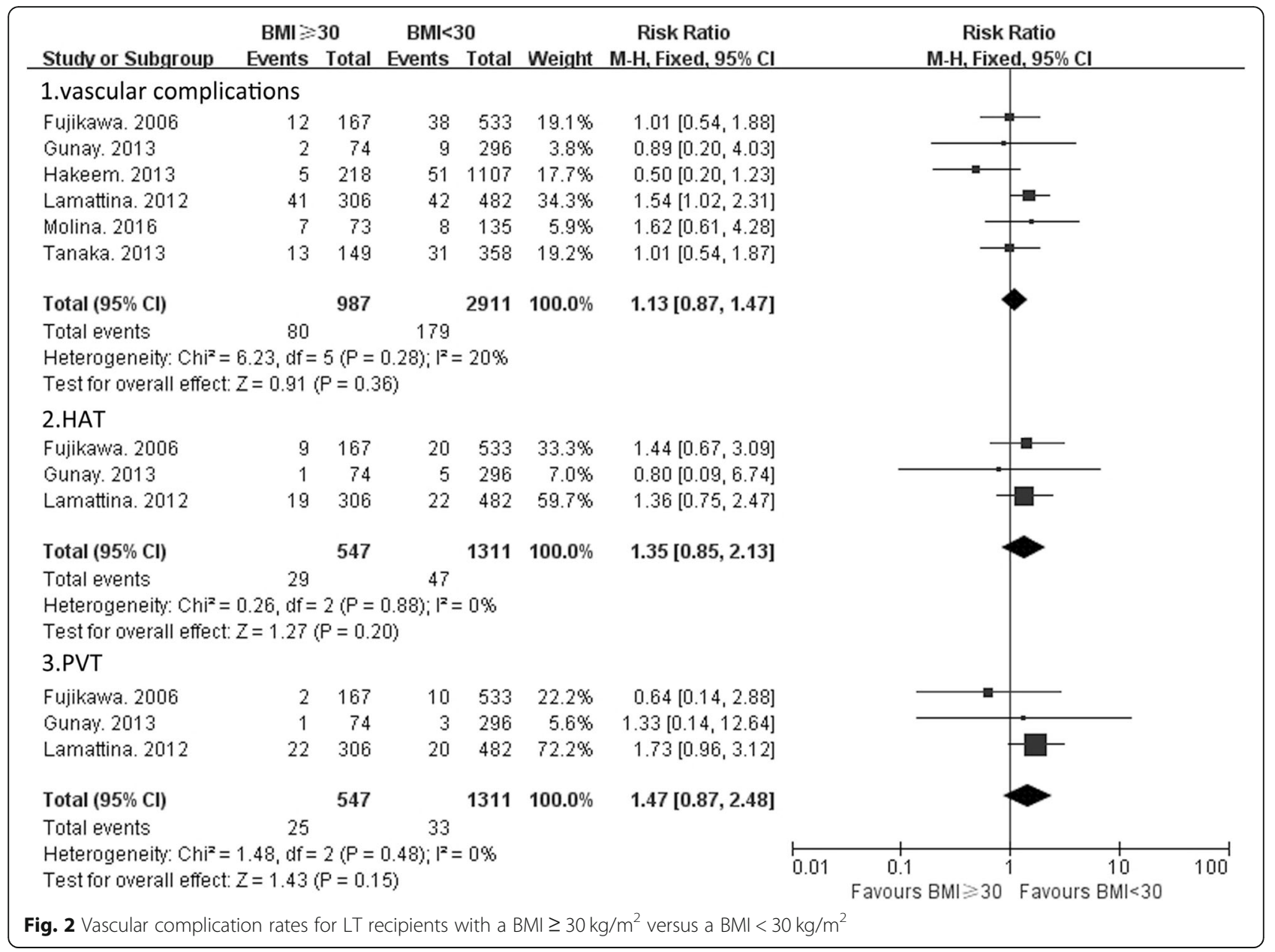

significant in the 3 studies that reported 5-year patient survival rates $\left(X^{2}=3.59, P=0.17, \mathrm{I}^{2}=44 \%\right)$. Therefore, a random-effects model was used to pool the overall results for 1 - and 3-year survival rates, and a fixed-effects model was used for analysis of 5 -year survival rates. For patients with a $\mathrm{BMI} \geq 30$ $\mathrm{kg} / \mathrm{m}^{2}$, the RR for 1-, 3- and 5- survival was 0.99 (95\% CI: 0.89-1.09, $P=0.77$ ), 0.94 (95\% CI: 0.82-1.08, $P=0.40)$, and 0.96 (95\% CI: $0.90-1.04, \quad P=0.32)$. There was no significant difference in the 1-, 3-, and 5 -year survival rate between the 2 groups.

\section{Graft survival}

Three studies reported 1-year graft survival rate [16, $21,23]$. The heterogeneity among these studies was not significant $\left(X^{2}=2.29, \mathrm{P}=0.32 ; \mathrm{I}^{2}=13 \%\right)$; thus, a fixed-effects model was used. There was no significant difference in 1-year graft survival between patients with a BMI $\geq 30 \mathrm{~kg} / \mathrm{m}^{2}(n=459)$ and a BMI $<30 \mathrm{~kg} / \mathrm{m}^{2}$ $(n=1936) \quad(\mathrm{RR}=0.98, \quad 95 \% \quad \mathrm{CI}: \quad 0.94-1.02, \quad P=0.35)$ (Fig. 4).

\section{Biliary complications}

We further evaluate the rate of biliary complications. Four studies including 765 patients with a BMI $\geq 30 \mathrm{~kg} / \mathrm{m}^{2}$ and 2418 patients with a $\mathrm{BMI}<30 \mathrm{~kg} / \mathrm{m}^{2}$ were included in the analysis of biliary complications [13, 16, 21, 23]. No significant difference between the 2 groups was noted ( $R R=1.07$, 95\% CI: 0.92-1.25, $P=0.37$ ) (Fig. 4).

\section{Discussion}

As the number of obese persons rises globally, the trend that obese patients make up a growing proportion of LT recipients is unavoidable. There is no certain conclusion whether obesity impacts the incidence of post-transplant vascular complications in LT patients. This is the first meta-analysis to examine the association of obesity with vascular complications after LT. The results of our study indicate that obesity does not increase the rate of vascular complications in LT recipients, nor does obesity increase the rate of HAT or PVT. However, in pooled analysis of 2 studies where the indication for LT was alcoholic cirrhosis, obese patients had significantly higher incidence of vascular complications. 


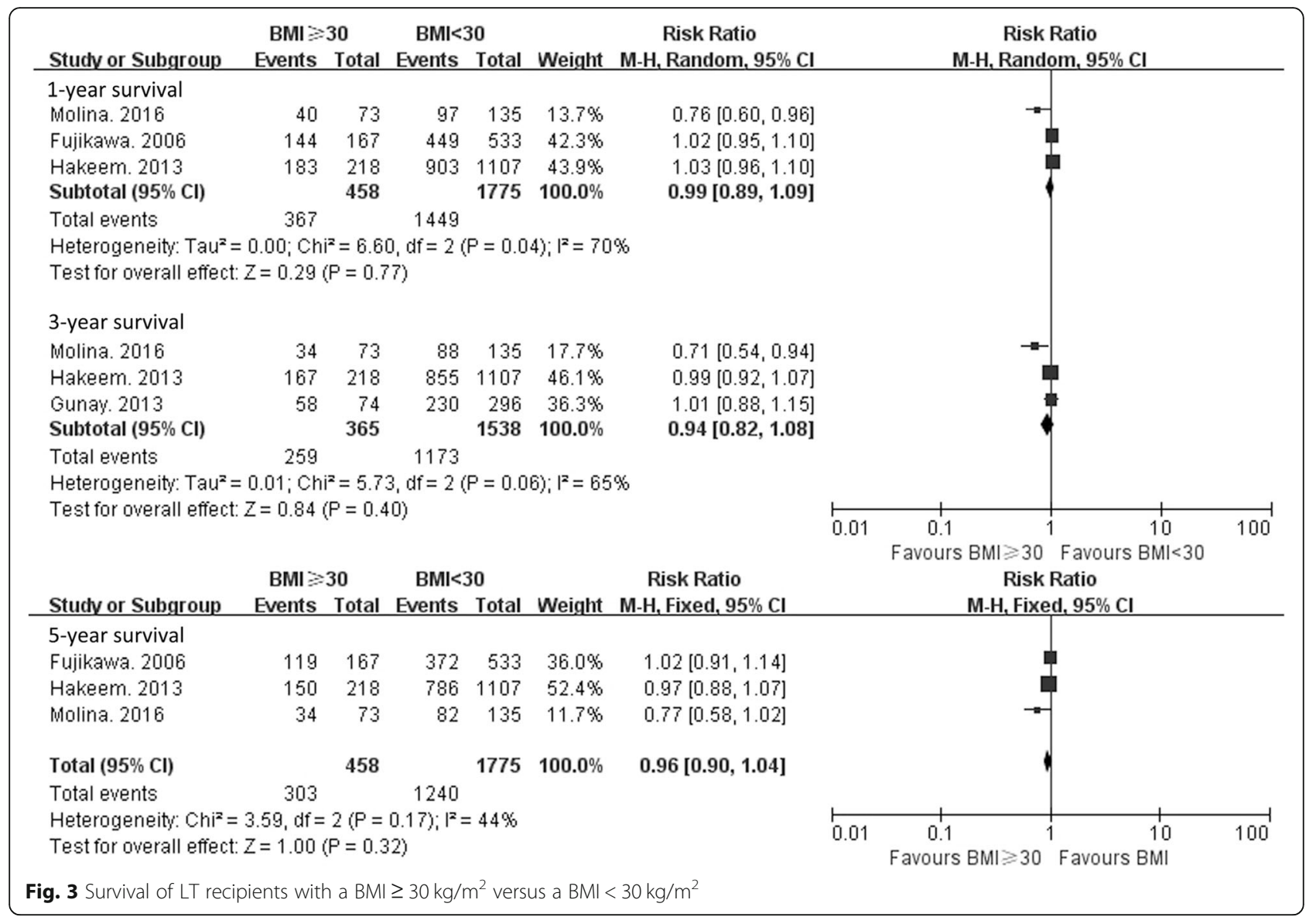

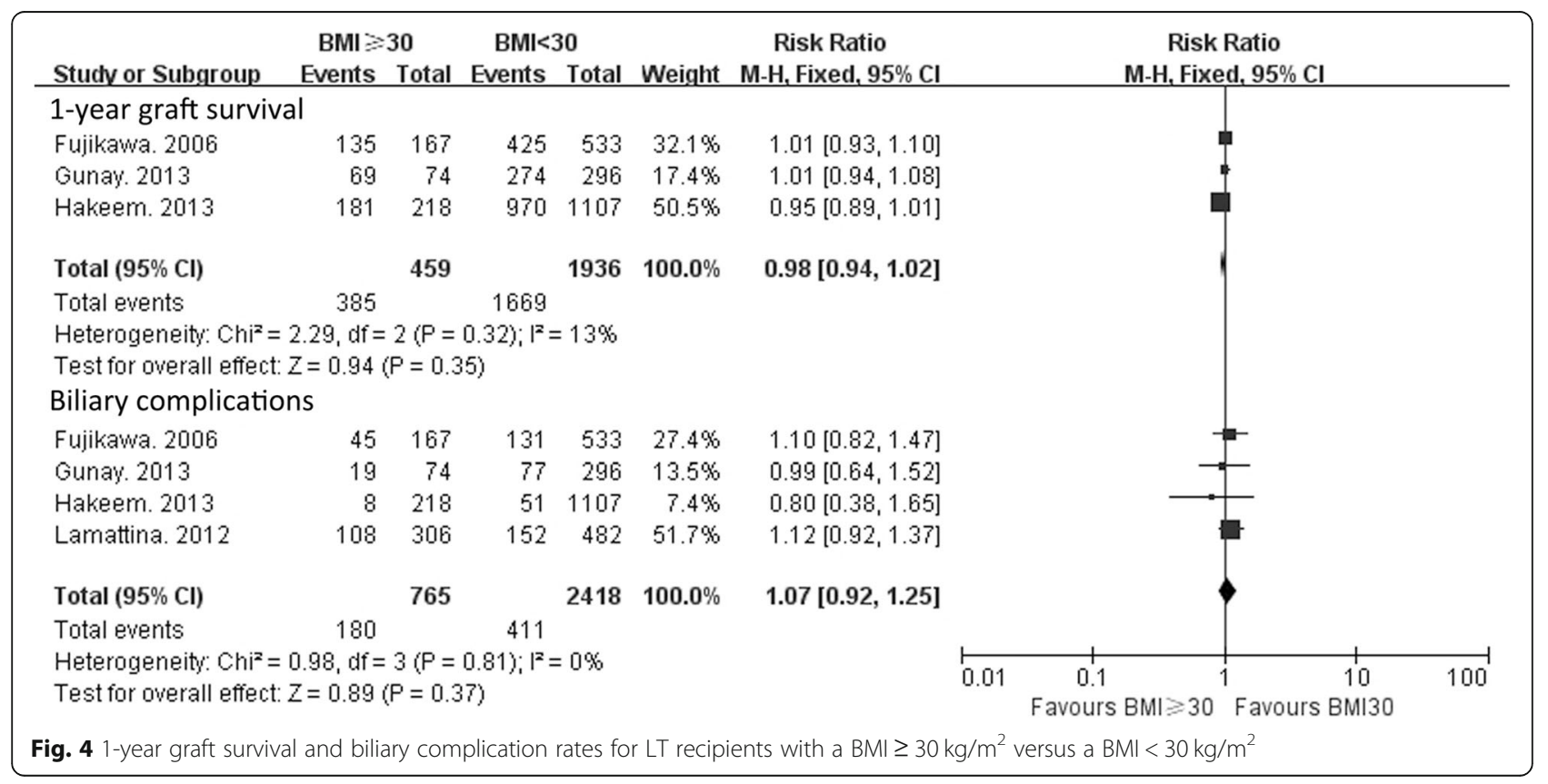


Subgroup analysis performed according to different BMI thresholds and adjustment of BMI for ascites also failed to identify any significant difference between patients with a BMI $\geq 30 \mathrm{~kg} / \mathrm{m}^{2}$ and a $B M I<30 \mathrm{~kg} / \mathrm{m}^{2}$. Similarly, a review of the United NetWork of Organ Sharing (UNOS) database (1987-2001) that included 9701 pediatric LT recipients showed that the vascular thrombosis rate was not higher in obese versus non-obese recipients [19]. However, a retrospective analysis of renal transplantation including 1095 patients found the risk of post-transplant vascular complications within 1 year was greater when grafts were transplanted with multiple arteries in obese recipients compared to their non-obese counterparts [25]. The hypercoagulable and proinflammatory state associated with obesity predisposing to both arterial and venous thrombosis was proposed to explain the result.

La Mattina et al. [13] thought that technical difficulties and a high rate of metabolic syndrome in obese LT recipients contribute to a higher rate of post-transplant vascular complications. However, the reasons for this are not clear and probably multi-factorial. We propose some reasons that may explain the lack of association between obesity and post-transplant outcomes in LT recipients. It is possible that obesity, in fact, does not impact the occurrence of vascular complications. In addition, there is strict screening of patients prior to LT, and optimization of risk factors. Another explanation is that BMI does not accurately represent the degree of obesity. The distribution of fat deposition is not accounted for in BMI. Study has shown that visceral adiposity, but not peripheral adiposity, is associated with increased mortality after LT [26].

In the analysis of 3 studies that reported the patient survival, we found no difference in the 1-, 3-, and 5-year survival between patients with a $\mathrm{BMI} \geq 30 \mathrm{~kg} / \mathrm{m}^{2}$ and $\mathrm{BMI}<$ $30 \mathrm{~kg} / \mathrm{m}^{2}$. Some recent publications also reported no significant association between obesity and patient survival after LT [7, 27]. Biliary complications are intrinsically linked with hepatic arterial pathology [28-30]. Our analysis showed no difference in the rate of biliary complications between obese versus non-obese LT recipients.

There are some limitations to this study. First, there were no randomized controlled trials published; all of the included studies were retrospective cohort studies. The quality of the studies was not satisfactory because none of them adjusted for confounders. As such, heterogeneity between studies was unavoidable. Second, all of the included studies were single-center studies. In addition, none of the studies described how complications were diagnosed.

\section{Conclusions}

The current analysis indicates that obesity does not increase the rate of vascular complications in LT recipients.
Patient survival at 1-, 3-, and 5-years and the biliary complication rate were also similar between obese and non-obese patients. Overall, a high BMI should not be a contraindication for LT. However, obese recipients with alcoholic liver disease and metabolic syndrome should be monitored closely for vascular complications.

\section{Additional files}

Additional file 1: Vascular complications rate for $L T$ recipients with $B M I \geq 35$ versus $B M I<25$. (TIF $1388 \mathrm{~kb}$ )

Additional file 2: Vascular complications rate for $\mathrm{LT}$ recipients with BMI of 30-35 versus $18-25$. (TIF $1448 \mathrm{~kb}$ )

Additional file 3: Vascular complications rate for $\mathrm{LT}$ recipients with $\mathrm{BMI} \geq 30$ versus $18-25$. (TIF $1445 \mathrm{~kb}$ )

Additional file 4: Vascular complications rate for $L T$ recipients with $\mathrm{BMI} \geq 35$ versus $<35$. (TIF $1386 \mathrm{~kb}$ )

Additional file 5: Vascular complications rate for $L T$ recipients with $\mathrm{BMI} \geq 30$ versus $<30$ in studies adjusted BMI for ascites. (TIF $1386 \mathrm{~kb}$ )

\section{Abbreviations}

BMI: Body mass index; Cl: Confidence interval; HAT: Hepatic arterial thrombosis; HBV: Hepatic B virus; HCV: Hepatic C virus; LT: Liver transplantation; MELD: Model for end-stage liver disease; PVT: Portal venous thrombosis; RevMan: Review Manager; RR: Risk ratio; UNOS: United NetWork of Organ Sharing; WHO: the World Health Organization

\section{Acknowledgements}

Not applicable.

\section{Funding}

This work was supported by grants from the National Natural Science Foundation of China, China (81370574, and 81670591), Guangdong Natural Science Foundation, China (2016A030311028), and the Science and Technology Program of Guangzhou, China (201704020073).

Availability of data and materials

All data generated or analysed during this study are included in this published article (and its supplementary information files).

\section{Authors' contributions}

YS, BH, RD, YM Research concept and design. YS, BH, RD, Assessment of quality and Collection of data. YS, BH, Data analysis. YS, BH, Writing the article. RD, YM Critical revision of the article. RD and YM approved the final manuscript. All authors read and approved the final manuscript.

Ethics approval and consent to participate

Not applicable. All analyses were based on previous published studies,thus no ethical approval and patient consent are required.

Consent for publication

Not applicable.

Competing interests

The authors declare that they have no competing interests.

\section{Publisher's Note}

Springer Nature remains neutral with regard to jurisdictional claims in published maps and institutional affiliations. 
Received: 4 April 2018 Accepted: 19 February 2019

Published online: 07 March 2019

\section{References}

1. World Healthy Organization. Prevalence of obesity among adults, BMI $\geq 30$, 2016. Available at http://apps.who.int/gho/data/view.main. BMI30CREGv?lang=en. Assessed 28 Sept 2017.

2. Stepanova M, Younossi ZM. Independent association between nonalcoholic fatty liver disease and cardiovascular disease in the US population. Clin Gastroenterol Hepatol. 2012;10:646-50.

3. Lazo M, Hernaez R, Eberhardt MS, Bonekamp S, Kamel I, Guallar E, Koteish A et al. Prevalence of nonalcoholic fatty liver disease in the United States: the third National Health and nutrition examination survey, 1988-1994. Am J Epidemiol. 2013;178:38-45

4. Flegal KM. Epidemiologic aspects of overweight and obesity in the United States. Physiol Behav. 2005;86:599-602.

5. Flegal KM, Carroll MD, Kit BK, Ogden CL. Prevalence of obesity and trends in the distribution of body mass index among US adults, 1999-2010. JAMA 2012;307:491-7

6. Wang Y, Beydoun MA. The obesity epidemic in the United Statesgender, age, socioeconomic, racial/ethnic, and geographic characteristics: a systematic review and meta-regression analysis. Epidemiol Rev. 2007;29:6-28.

7. Bambha KM, Dodge JL, Gralla J, Sprague D, Biggins SW. Low, rather than high, body mass index confers increased risk for post-liver transplant death and graft loss: risk modulated by model for end-stage liver disease. Liver Transpl. 2015;21:1286-94.

8. Nair S, Vanatta JM, Arteh J, Eason JD. Effects of obesity, diabetes, and prior abdominal surgery on resource utilization in liver transplantation: a singlecenter study. Liver Transpl. 2009;15:1519-24.

9. Pelletier SJ, Schaubel DE, Wei G, Englesbe MJ, Punch JD, Wolfe RA, Port FK, et al. Effect of body mass index on the survival benefit of liver transplantation. Liver Transpl. 2007;13:1678-83.

10. Piardi T, Audet M, Panaro F, Gheza F, Cag M, Portolani N, Cinqualbre J, et al. Incisional hernia repair after liver transplantation: role of the mesh. Transplant Proc. 2010;42:1244-7.

11. Perez-Saborido B, Pacheco-Sanchez D, Barrera-Rebollo A, Asensio-Diaz E, Pinto-Fuentes P, Sarmentero-Prieto JC, Rodriguez-Vielba P, et al. Incidence, management, and results of vascular complications after liver transplantation. Transplant Proc. 2011;43:749-50

12. Kamran HKS, Mirzakhani H, Eslami M, Saidi RF. Current state of the art in management of vascular complications after pediatric liver transplantation. Pediatr Transplant. 2015;19:18-26.

13. LaMattina JC, Foley DP, Fernandez LA, Pirsch JD, Musat Al, D'Alessandro AM, Mezrich JD. Complications associated with liver transplantation in the obese recipient. Clin Transpl. 2012;26:910-8.

14. Molina AR, Vilchez AR, Dominguez MB, Garcia AN, San MC, Gonzalez AR, Fundora YS. Influence of body mass index on venous thrombotic complications of liver transplants. Transplant Proc. 2016:48:3017-20.

15. Nair S, Cohen DB, Cohen MP, Tan H, Maley W, Thuluvath PJ. Postoperative morbidity, mortality, costs, and long-term survival in severely obese patients undergoing orthotopic liver transplantation. Am J Gastroenterol. 2001;96: 842-5.

16. Hakeem AR, Cockbain AJ, Raza SS, Pollard SG, Toogood GJ, Attia MA, Ahmad $\mathrm{N}$, et al. Increased morbidity in overweight and obese liver transplant recipients: a single-center experience of 1325 patients from the United Kingdom. Liver Transpl. 2013;19:551-62.

17. Spengler EK, O'Leary JG, Te HS, Rogal S, Pillai AA, Al-Osaimi A, Desai A, et al. Liver transplantation in the obese cirrhotic patient. Transplantation. 2017; 101:2288-96.

18. Saab S, Lalezari D, Pruthi P, Alper T, Tong MJ. The impact of obesity on patient survival in liver transplant recipients: a meta-analysis. Liver Int. 2015; 35:164-70.

19. Dick AA, Perkins JD, Spitzer AL, Lao OB, Healey PJ, Reyes JD. Impact of obesity on children undergoing liver transplantation. Liver Transpl. 2010;16: 1296-302.

20. Molina RA, Garcia NA, San MMC, Dominguez BM, Villegas HM, Granero K, Becerra MA, et al. Influence of obesity on liver transplantation outcomes. Transplant Proc. 2016:48:2503-5.
21. Fujikawa T, Fujita S, Mizuno S, Shenkman E, Vogel B, Lipori P, Hemming AW, et al. Clinical and financial impact of obesity on the outcome of liver transplantation. Transplant Proc. 2006;38:3612-4.

22. Tanaka T, Renner EL, Selzner N, Therapondos G, Lilly LB. The impact of obesity as determined by modified body mass index on long-term outcome after liver transplantation: Canadian single-center experience. Transplant Proc. 2013;45:2288-94.

23. Gunay Y, Guler N, Dayangac M, Taskesen F, Yaprak O, Emek E, Akyildiz M, et al. Living donor liver transplantation for obese patients: challenges and outcomes. Liver Transpl. 2014;20:311-22.

24. Triquero J, Garcia A, Molina A, San MC, Notario P, Villegas T, Becerra A, et al. Complications associated with liver transplantation in recipients with body mass index $>35 \mathrm{~kg} / \mathrm{m}(2)$ : would it be a poor prognosis predictive factor? Transplant Proc. 2015;47:2650-2.

25. Nath J, Mastoridis S, van Dellen D, Guy AJ, McGrogan DG, Krishnan H, Pattenden C, et al. Complex kidneys for complex patients: the risk associated with transplantation of kidneys with multiple arteries into obese patients. Transplant Proc. 2015;47:373-8.

26. Terjimanian MN, Harbaugh CM, Hussain A, Olugbade KJ, Waits SA, Wang SC, Sonnenday CJ, et al. Abdominal adiposity, body composition and survival after liver transplantation. Clin Transpl. 2016;30:289-94.

27. Singhal A, Wilson GC, Wima K, Quillin RC, Cuffy M, Anwar N, Kaiser TE, et al. Impact of recipient morbid obesity on outcomes after liver transplantation. Transpl Int. 2015;28:148-55.

28. Zhu KS, Meng XC, Huang MS, Qian JS, Guan SH, Li ZR, Jiang ZB, et al. The role of early hepatic artery ischemia on biliary complications after liver transplantation and hepatic arterial interventional therapy. Zhonghua Yi Xue Za Zhi. 2009:89:2195-8.

29. Kim PT, Saracino G, Jennings L, Ramsay M, McKenna GJ, Testa G, Anthony $T L$, et al. Ratio of hepatic arterial flow to recipient body weight predicts biliary complications after deceased donor liver transplantation. HPB (Oxford). 2014;16:1083-7.

30. Zheng SS, Xu X, Liang TB, Chen HY, Wang WL, Wu J. Biliary complications following early hepatic arterial insufficiency in liver transplantation. Zhonghua Yi Xue Za Zhi. 2005:85:1665-9.

Ready to submit your research? Choose BMC and benefit from:

- fast, convenient online submission

- thorough peer review by experienced researchers in your field

- rapid publication on acceptance

- support for research data, including large and complex data types

- gold Open Access which fosters wider collaboration and increased citations

- maximum visibility for your research: over $100 \mathrm{M}$ website views per year

At $\mathrm{BMC}$, research is always in progress.

Learn more biomedcentral.com/submissions 